been taking place in response to these changes as they occurred, while in the future continuous adaptation will be required. Britain has now entered a period in which planning-conscious direction and intelligent anticipation-is essential to national welfare. Industry is already striving towards that integration and unity which modern conditions demand, and these efforts must be assisted. A sufficient measure of centralisation of control is required to enable the activities of separate industries to be brought into harmony with the economic objectives essential to national welfare and prosperity as a whole. The units of productive effort need to be controlled by a coordinating central authority sufficiently representative and sufficiently powerful to direct capital and labour into the correct channels to maintain equilibrium. Even already, Britain has been moving into this field of conscious endeavour by the road of protection, agricultural marketing, the regulation of wheat and coal production, the centralised direction of electrical power distribution, and now by the subordination of credit to the needs of industry. Mistakes have, of course, been made in the past, but improvements will have to be carried out as experience is gained.

\section{New Index Number of Profits}

IN his valedictory address on June 21 as president of the Royal Statistical Society, Sir Josiah Stamp described a new index number of profits, which he has constructed. This consists of a general index of profits designed to show changes in the return to capital as a whole and a special sub-index showing variations in the return for risk-bearing capital (ordinary shares, etc.). Both indices are comparable with the index of production, the various price indices, and other statistics. For technical reasons, the year 1924 has been selected as the base period, but the numbers have been carried back to 1920 as shown in the following table:

\begin{tabular}{|c|c|c|}
\hline Year. & Generai Index. & Special Index. \\
\hline 1920 & $107 \cdot 0$ & $112 \cdot 0$ \\
1921 & $68 \cdot 7$ & $57 \cdot 3$ \\
1922 & $90 \cdot 4$ & $84 \cdot 6$ \\
1923 & $94 \cdot 1$ & $90 \cdot 6$ \\
1924 & $100 \cdot 0$ & $100 \cdot 0$ \\
1925 & $104 \cdot 1$ & $109 \cdot 3$ \\
1926 & $98 \cdot 3$ & $103 \cdot 0$ \\
1927 & $106 \cdot 5$ & $111 \cdot 4$ \\
1928 & $106 \cdot 2$ & $110 \cdot 7$ \\
1929 & $109 \cdot 9 *$ & $114 \cdot 3$ \\
1930 & $100 \cdot 9 \dagger$ & $94 \cdot 4$ \\
1931 & $92 \cdot 0 \dagger$ & $80 \cdot 9 *$ \\
\hline
\end{tabular}

* Provisional, subject to eariy verification. $\uparrow$ Very provisional.

Sir Josiah Stamp pointed out that his index referred to changes in the aggregate amount of profits, and not to the rate of return on eapital. Inasmuch as a large increase has taken place in invested capital since 1924, the fall in the rate of return per unit of capital is greater than that of any fall indicated by the aggregate index. The index shows that the range of boom and depression is far smaller in Great Britain than in the United States.

No. 3270 , Vor. 130]

\section{The Patents and Designs Bill}

CONFIDENCE which was placed in the Joint Chemical Patents Committee on its formation has been fully justified by the record of its activity. This committee of the Association of British Chemical Manufacturers, on which the Chemical Society, the Institute of Chemistry, and the Institution of Chemical Engineers are represented, gave evidence before the Board of Trade Departmental Committee on the Patents and Designs Acts and the practice of the Patent Office, during the inquiry which extended over eighteen months. The Patents and Designs Bill recently introduced into Parliament proposes to give effect to the recommendations of this Departmental Committee, generally known as the Sargant Committee; on publication, the Bill was examined by the Joint Chemical Patents Committee, and was considered still to contain a number of points of importance requiring amendment. As a result of the presentation of a memorandum to the Board of Trade, followed by a deputation, almost all the desired amendments have been secured at the committee stage of the Bill. For example, more effective provision for dealing with the abuse of user patents, whereby the manufacture of non-patented substances was being restricted or entirely prevented in Great Britain, has been obtained. The section dealing with the remedy in case of groundless threats of legal proceedings has been amended, and the appeal tribunal is to have power to obtain the technical assistance of an assessor in all cases. So far as the costs of appeal are concerned, the present atmosphere of appeals to the law officer is to be preserved, although in certain respects the tribunal will be regarded as a court of the High Court. It is a valid claim that these major amendments will both strengthen the new Act and afford great assistance to the poor inventor.

\section{Prof. H. Brereton Baker}

ON the occasion of his seventieth birthday, Prof. H. Brereton Baker and Mrs. Baker were, on June 25, entertained at dinner at the Imperial College of Science and Technology by a number of colleagues and former pupils. The rector of the Imperial College, Mr. H. T. Tizard, presided, and the company included distinguished representatives of those who had been associated with Prof. Baker's work at Dulwich College, at the University of Oxford, and at the Imperial College, London. Ave was, however, accompanied by Vale, for at the end of the present academic year Prof. Baker retires from the directorship of the Chemistry Department of the Imperial College and from his chair of chemistry in the University of London; fortunately, however, Prof. Baker will continue actively to prosecute his researches, and will occupy accommodation which has been placed at his disposal for that purpose by the College. Tribute was paid to Prof. Baker's work, both for chemical science and for the institutions with which he has been associated, by Mr. Tizard, Mr. R. T. Lattey, Mr. D. L. Chapman, and Prof. H. E. Armstrong. During the evening an inscribed album was presented to Prof. Baker, and Mrs. Baker was asked to accept a piece 